\title{
A transformação das identidades uma empresa de telecomunicações antes e depois de sua privatização: um estudo de metáforas ${ }^{i}$
}

Alexandre de Pádua Carrieri ${ }^{\text {ii }}$

Resumo: O objetivo deste trabalho é estudar as metáforas como formas de pensar e ver as identidades da organização. $\mathrm{Na}$ abordagem empírica dessa problemática, procedeu-se a um estudo de caso em uma empresa do setor de telecomunicações em Minas Gerais - a Telemig. Focalizou-se a história dessa organização durante toda a década de noventa e sua transformação de empresa pública para filial de uma holding privada. $\mathrm{Na}$ construção das narrativas sobre essa transformação, pode-se observar nos grupos estudados algumas metáforas que buscavam descrever o como as pessoas viam a empresa e como elas se identificavam com ela. Assim, para a alta administração a empresa é identificada como a número um ou referência; para o sindicato como a caverna e a grande pecadora; para os gerentes como grande família e vaca leiteira; e para os técnicos como a mãe e a madrasta.

Palavras-chaves: identidades, metáforas, narrativas, mudança organizacional.

Abstract: The goal of this work is to study the metaphors as ways of thinking about and seeing the identities of an organization. In the empirical approach used in the research, a case study was carried out in a corporation of the telecommunications sector in the state of Minas Gerais, the Telemig. The case study covers the history of the Telemig throughout the whole decade of 1990 and its transformation from a public agency into a branch of a private holding. In the construction of the narratives about this transformation, one can observe in the groups analyzed the use of metaphors which attempted to describe not only the ways such groups perceived the organization, but also the ways they identified themselves with it. This way, by the top administration, the organization is identified as a number one or a reference; by the union, as the cave and the great sinner; by the managers, as the big family and the dairy cow; and by the technicians, as the mother and the stepmother.

\section{Introdução}

Este trabalho originou-se do um estudo sobre cultura nas organizações. Buscou-se evidenciar a transformação cultural de uma empresa do setor de telecomunicações - a Telemig, durante a década de noventa. Para reconstruir esse processo de transformação foram coletadas aproximadamente 100 entrevistas e grande quantidade de material impresso. $\mathrm{Na}$ análise dos dados coletados, observou-se uma grande quantidade de metáforas usadas, principalmente, para descrever a empresa durante o processo de privatização. É este o objetivo deste trabalho, isto é, analisar as metáforas - como formas de pensar e ver as identidades da organização (MORGAN, 1996; GRANT e OSWICK, 1996) estudada, que aparecem nos discursos dos diferentes grupos que compõem a Telemig na sua transformação de empresa pública em filial de uma holding privada.

Pelos estudos da identidade enriquece-se a compreensão das culturas e pelo estudo da cultura compreendem-se as identidades. A interdependência da cultura e da identidade torna-as 
vulneráveis a qualquer transformação em uma delas. $\mathrm{Na}$ busca por sua identidade e na interação com o ambiente, os indivíduos, grupos e organizações são induzidos a introjetarem símbolos, valores, signos, mitos e histórias que vão confirmando ou reforçando uma cultura e uma identidade que, muitas vezes, não lhes pertence. Descarta-se a difícil construção de uma identidade própria, aceitando-se algo que está pronto e que oferece, de certa forma, um sentido à pessoa, ao grupo e à organização (RODRIGUES, 1991).

Para muitos autores, como FEATHERSTONE (1995) e FRIEDMAN (1994), o mundo atual passa por uma crise cultural global. Procuram-se a todo o momento símbolos para a edificação de vínculos com o mundo social e para a construção de uma identidade. Os símbolos são consumidos aos borbotões, mas são incapazes de promover vínculos duradouros, seja na família, seja nas instituições etc. A crise cultural global trouxe uma crise de identidade que atinge indivíduos, grupos, organizações e instituições. Para esses autores, com o processo de globalização, o centro (países ricos) tem conseguido fazer com que indivíduos, grupos e organizações dos países periféricos tenham a possibilidade de se perceber como integrados ao primeiro mundo, promovendo uma identificação positiva com o privado/mercado, com as reengenharias e as qualidades totais, mudanças tecnológicas, etc.

No ambiente organizacional, o processo de globalização e o tema do livre mercado impelem as propostas de reestruturação, caracterizadas pelos programas de qualidade total, reengenharia, downsizing, core business, vantagens competitivas, entre outros. Em seu trabalho DU GAY et al. (1996) colocam que, nos anos oitenta, nos países centrais, configurou-se um discurso fundador que propunha o tema das reformas, reestruturações organizacionais. $\mathrm{O}$ discurso servia de referência a outros discursos que enfatizavam satisfação total do cliente/consumidor, administração de RH, qualidade total, reengenharia, downzising, vantagens competitivas, core business, etc. Todos esses discursos e suas práticas permitiriam a construção de uma organização flexível, muito pouco burocrática, criativa, empreendedora.

Nesse sentido, os discursos indicariam a necessidade tanto de uma grande transformação organizacional quanto da criação de novas subjetividades, de uma nova identidade - organizacional e individual - e, no fundo, a criação de uma nova cultura organizacional.

\section{A Pesquisa sobre o Tema da Identidade nas Organizações}

O estudo sobre cultura é inter-relacionado e interdependente do estudo a respeito da identidade. Segundo autores como RODRIGUES (1995), ALVESSON (1998), MACHADO-daSILVA e NOGUEIRA (2000), cultura e identidade se completam na medida em que uma 
necessita da outra como fonte de significados. Segundo FIOL et al. (1998), a identidade sempre é definida em relação a um sistema de significações, valores, ideologias, enfim, em relação a uma ou várias culturas. Nesse sentido, a identidade de uma organização sempre é afetada pelas significações culturais que perpassam as empresas e, como colocam BORZEIX e LINHART (1996), ela nunca é única, variando de acordo com as situações e a história dos atores organizacionais.

Para autores como NKOMO e COX JUNIOR (1996), a dimensão simbólico-cultural é historicamente construída e, por isso mesmo, está sempre sujeita a contradições e ambigüidades no decorrer da vida de um grupo, de uma organização. Tanto o contexto externo da organização como o interno - as culturas - devem ser estudados para que se possa compreender as transformações ocorridas nas identidades, nos valores, normas e na interação entre as pessoas. As contradições e as ambigüidades podem criar não uma, mas várias identidades nas organizações. Dessa forma, é preciso que qualquer estudo a respeito de cultura e de identidade consiga destacar essa fluidez, essa dinâmica e crescente transformação histórica pela qual passa uma organização, um grupo, um indivíduo. Segundo ALVESSON (1994) a cultura proporciona as bases para a construção das identidades; o conjunto de símbolos, os ritos, mitos, as histórias e visões de mundo são elementos para a edificação e modelação de identidades.

Em seu trabalho sobre identidade organizacional, CALDAS e WOOD JÚNIOR (1997) constróem um quadro conceitual onde localizam as diversas abordagens do conceito de identidade. Para efeito didático, distribuem os estudos pertinentes à identidade em seis agrupamentos:

1. Estudos sobre identidade individual, com referencial teórico na Psicanálise;

2. Estudos referentes à identidade como autoconceito, com fortes influências da Psicologia Social. Nesse agrupamento, o conceito de identidade deixaria de ser somente atributo do indivíduo, mas seria um atributo de grupos e organizações.

3. Estudos derivados dos trabalhos de ALBERT e WHETTEN (1985), os quais conceituam identidade organizacional como "crenças compartilhadas pelos membros sobre o que é (a) central, (b) distintivo, e (c) duradouro na organização. $\mathrm{O}$ critério de centralidade aponta as características vistas como a essência da organização. O critério de distintividade aponta os elementos que distinguiriam uma organização das outras com as quais poderia ser comparada. Por fim, o critério de continuidade temporal ressalta as características estáveis no tempo" (CALDAS e WOOD JÚNIOR, 1997: 12). 
4. Estudos recentes (anos 80 e 90), com forte influência da Psicologia Social. A identidade organizacional teria a função de informar como a organização se percebe. Desse agrupamento surgiram pesquisas sobre a identidade do indivíduo, dos grupos e da organização.

5. Estudos mais instrumentais, pragmáticos, nos quais a identidade é analisada via imagem. Sendo a imagem uma interpretação do pensamento de outros, analisa-se como a organização administra sua imagem no ambiente.

6. Estudos que discutem a identidade em nível macro, das nações.

Para esses autores, uma análise desses seis agrupamentos permite observar que os estudos sobre identidade a caracterizam:

- partindo do indivíduo para o coletivo - organização, países;

- partindo do ponto de vista interno - da auto-imagem - para o externo - imagem como uma interpretação do pensamento dos outros.

São caminhos que se cruzam a todo o momento, assim como os agrupamentos referidos acima, criando possibilidades de estudos que permitem observar como os indivíduos e grupos vêem a organização, como a organização (a alta administração) se vê, como percebe que o ambiente a vê, etc.

GLYNN e ABZUG (2001) também realizam uma retrospectiva teórica sobre os estudos organizacionais em identidade e evidenciam que os caminhos teóricos se cruzam e criam inúmeras possibilidades de pesquisa. Mas, diferentemente de Caldas e Wood Júnior, eles apenas caracterizam duas grandes abordagens teóricas. A primeira perspectiva enfatiza o papel dos atributos organizacionais na construção de uma identidade tanto da empresa como dos indivíduos. De acordo com esta abordagem a identidade é uma construção que define uma organização em termos das características que lhe são centrais, distintas e duradouras. Para essa abordagem, a identidade deixa de ser focalizada como imposta por uma alta administração, mas como a identidade é construída pelos diferentes grupos organizacionais. A outra abordagem é relacional, enfatizando como a identidade localiza, classifica uma organização em determinado espaço (e tempo). Esta perspectiva dirige a atenção da configuração dos atributos internos para o nível interorganizacional, como a identidade transcende os limites organizacionais. Ao final, as duas perspectivas se complementam.

ALBERT e WHETTEN (1985) e ALVESSON (1998) também consideram que existem na TO duas perspectivas para o estudo da identidade: a holográfica e a ideográfica. De acordo com a primeira perspectiva, a identidade existente e predominante é a da alta administração; ela percorreria toda organização e poderia ser evidenciada em qualquer parte desta. A segunda perspectiva considera a identidade múltipla, isto é, pode-se estudar identidade pela pesquisa em 
cultura nas organizações, podendo haver, desse modo, não uma identidade, mas várias (ALBERT, 1998). Assim, existiria a identidade dos grupos, dos indivíduos e da alta administração). Essa perspectiva casa com a abordagem de MARTIN (1992) a respeito do estudo de cultura. Tanto se pode falar de uma identidade integradora, patrocinada pela alta gerência, que supõe uma identidade homogênea, duradoura, única, passível de ser criada e modelada, como também de identidades grupais e de uma identidade fragmentada da organização.

O estudo da identidade holográfica e integradora parece ser o mais difundido na TO, como mostram autores como ALVESSON (1998), DUTTON e DURKERICH (1991), BALMER e WILSON (1998). Para esses autores, o estudo da identidade integradora traz também o conhecimento da imagem da organização. A identidade, nesses estudos, representa o que os "membros" acreditam ser suas características, e a imagem descreveria o que os "atores" organizacionais "acham" que os de fora pensam sobre eles, sendo então a imagem uma interpretação do pensamento de outros e um esforço da organização em expor a sua identidade para o ambiente. $\mathrm{O}$ interessante a se destacar, é que nessa abordagem, assim como na referente à cultura, generaliza-se o que a alta administração descreve como identidade e imagem, ocultandose a existência dos outros atores organizacionais e consequentemente a diferenciação e fragmentação da identidade e da imagem. Segundo REED (1998), a grande prioridade cultural da alta administração é tentar manter uma coesão e uma identidade que legitimem e dêem sentido às novas formas de controle e que também criem novas significações, novas subjetividades. Dessa maneira, os estudos de TO que pesquisam a identidade como única e integradora asseguram e viabilizam as novas formas de controle gerencial engendradas para cooptar e fazer cooperar os demais atores organizacionais.

Para FREITAS (2000b), a identidade pode ser conceituada como sendo um resultado, um estado psicossocial, que pode variar no tempo, não sendo, portanto, fixa. Pode-se referir ao indivíduo, ao grupo, à organização e à sociedade em geral. Assim, os núcleos identitários são a fonte de coerência interna que caracteriza um ser que tem consciência da própria existência. É uma autocategorização que pode variar em conformidade com critérios como a nacionalidade, sexo, idade, profissão, cultura, história, dentre outros. A identidade, no entanto, não é simplesmente um decalque das identidades sociais existentes, na medida que inclui os atributos pessoais, as fantasias, as posses, a vida familiar, os relacionamentos, a atividade criativa, dentro outros, e, ainda, os sentimentos relacionados a todas essas variáveis simbólicas que o indivíduo utiliza para se conceituar e se ver no mundo.

DAVEL e MACHADO ( 2001) afirmam que os processos de construção das identidades, de maneira geral, podem ser mais intensos em épocas específicas da vida das 
pessoas, das organizações, da sociedade. Assim, em decorrência, a identidade não seria fixa e imutável e seria constituída pela síntese das múltiplas identificações que ocorrem em função da vinculação das pessoas a diferentes grupos sociais como a família, escola e trabalho, dentre outras.

No mundo de hoje, segundo FREITAS (2000: 9), diante da crise cultural e de identidade que as sociedades vêm enfrentando, as altas gerências têm buscado produzir um novo imaginário, onde "a organização aparece como grande, potente, nobre, perfeita, procurando captar os anseios narcisistas de seus membros e prometendo-lhes ser a fonte de reconhecimento, de amor, de identidade, podendo preenchê-los e curá-los de suas imperfeições e fragilidades". VERSIANI (1995) afirma, em seu estudo sobre a identidade gerencial no contexto da globalização, que a identidade coletiva - tanto de grupos como das organizações - emergem na construção de grupos pelos indivíduos. Nessa construção - grupal -, as significações culturais que percorrem tanto a sociedade como as organizações são fundamentais não apenas para a construção da identidade das pessoas, dos atores organizacionais, mas também para que esses indivíduos internalizem certas regras, normas, ritos, mitos e, principalmente, uma determinada visão de mundo que definiria, ao final, sua localização social, em termos de afiliação coletiva (ASHFORTH, 1998).

Esse processo de construção das identidades, segundo VERSIANI (1995), advém dos inúmeros discursos, narrativas que percorrem a sociedade, a organização, os grupos e que se constituem em uma rede de significações para o próprio indivíduo e para as outras pessoas. As narrativas organizacionais ajudam na construção das identidades ao expressarem regras, normas, costumes, enfim, as culturas nas organizações, localizando os indivíduos em determinado mundo. Nesse sentido, segundo CHANLAT (1992: 13), “a identidade coletiva emerge quando os indivíduos são capazes de constituir grupos e representarem os seus papéis integrados ao conjunto. Uma relação nós a nós que denotará o pertencimento do indivíduo a um coletivo".

De acordo com MACHADO-DA-SILVA e NOGUEIRA (2000), a identidade como fenômeno social resulta dos significados das interações mantidas pelo indivíduo em sua vida e na coletividade. Não é inata e tem uma natureza reflexiva, refletindo o modo como a pessoa se vê. Para esses autores os grupos e organizações também possuiriam uma identidade, formada através de um processo de aproximação da identidade dos indivíduos com a identidade dos grupos nos quais se insere.

BORZEIX e LINHART (1996) constataram, através de estudos sobre as relações entre a palavra, identidade e ação coletiva no interior das organizações, que a identidade não é 
dada, de uma vez por todas, pela posição que seus membros ocupam na instituição ou na categoria profissional ao qual pertencem. Ela é construída, logo ela varia. A identidade é construída em função dos inúmeros discursos e acontecimentos que a alimentam e atualizada em conformidade com as circunstâncias que lhe conferem voz e forma. Dessa forma, um mesmo grupo pode passar por diversas configurações de identidade nos diferentes momentos de sua história, conforme os recursos oferecidos pelas situações. Toda alteração de sua composição interna, todo rearranjo do ambiente técnico ou organizacional, todo episódio excepcional como um conflito, um acidente ou um ato de assistir reuniões pode colocar em questão, de forma momentânea ou definitivamente, esta configuração. A identidade coletiva aparece, então, como um “ ajuntamento provisório e precário, diretamente ligado às situações sociais de que, em parte, ela é um produto” (BORZEIX e LINHART , 1996: 105). Outra constatação é que, se existem, para um mesmo grupo, várias configurações possíveis de identidade, pode-se pensar, então, que nem sempre existe consenso no interior de um grupo sobre os traços mais importantes deste "fundo comum compartilhado de que a identidade coletiva seria a expressão". Para cada configuração haveria diferentes narrativas que simbolizariam o aspecto do momento da identidade. Assim a noção de identidade não levaria a uma visão holística dos fenômenos no âmbito dos grupos sociais. Ao contrário, a identidade coletiva se definiria como um ponto de equilíbrio precário entre identidades individuais e coletivas. Finalmente, afirmam as autoras que: se a identidade coletiva de um grupo pode mudar, se é permeável às situações e acontecimentos externos que a revelam a si mesma e lhe dão substância, se, apesar disso, seus membros se apropriam dela de maneiras diferentes, desiguais, então esta noção trata das relações sociais.

RODRIGUES (1995) ressalta que estudar a identidade pode evidenciar o porquê, o como e até que ponto o indivíduo incorpora significações e legisla para reforçá-las ou, ao invés disso, abandoná-las. Os indivíduos podem então escolher, confirmar, retificar significações culturais, histórias, mitos e cerimônias; endossar e até anular seus comportamentos. O’CONNOR (1995) elucida que o locus da produção das significações culturais, das identidades é o discurso. Assim sendo, pelo estudo dos discursos pode-se apreender as identidades organizacionais. Para ALBERT (1998), assim como para GLYNN e ABZUG (2001), o estudo das identidades organizacionais na TO correlaciona-se diretamente com os estudos da linguagem, da Análise dos Discursos (AD), mais precisamente com o estudo sobre as metáforas e narrativas existentes na organização.

\section{Percurso Metodológico: Estudo das Metáforas e Narrativas}


$\mathrm{Na}$ abordagem empírica dessa problemática, procedeu-se a um estudo de caso em uma empresa do setor de telecomunicações em Minas Gerais - a Telemig. Focalizou-se a história dessa organização durante toda a década de noventa e sua transformação de empresa pública para a filial de uma holding privada. Na construção das narrativas sobre essa transformação, pôde-se observar nos grupos estudados o uso de algumas metáforas que buscavam descrever como as pessoas viam a empresa e como se identificavam com ela. Para ALBERT (1998) e FIOL et al. (1998), o termo identificação está diretamente correlacionado com o estudo da identidade. Para esses autores o termo identificação usualmente refere-se à relação do indivíduo para com a organização, em o que esta organização representa para essa pessoa, e isso é expresso pelo discurso, nas narrativas e uso de metáforas. Na verdade, observou-se durante as entrevistas com as pessoas na empresa, que em suas narrativas apareciam inúmeras metáforas para descrever alguma situação vivida e clarificá-la para o pesquisador.

Para MUMBY e CLAIR (1997), as pesquisas sobre as histórias organizacionais ganham cada vez mais ênfase nos estudos organizacionais. Esses autores apontam que tanto o estudo das narrativas como das metáforas são fontes importantes para o conhecimento sobre as organizações. Pode-se estudar somente as histórias e observar como elas percorrem os diferentes grupos e atores organizacionais. Também pode-se pesquisar unicamente as metáforas, como formas, imagens que os indivíduos ou grupos constróem para fornecer sentido ao seu dia-a-dia nas organizações (GRANT e OSWICK, 1996). Todavia, deve-se sempre estudar as narrativas e metáforas como resultado de um processo, de uma construção social da realidade em que vivem os grupos e indivíduos nas organizações.

Para PUTNAM e FAIRHURST (2001), o estudo das metáforas na TO possibilita uma melhor compreensão dos discursos e contribui para a apreensão da realidade das organizações com a descrição dos universos simbólicos que surgem por trás das metáforas. Além disso, para esses autores a pesquisa sobre metáforas influenciaria a condução metodológica das pesquisas em organizações, pois possibilita utilizar as metáforas como ferramentas qualitativas. INNS e JONES (1996) apontam uma evolução do uso da AD nos estudos organizacionais em relação às metáforas, que passam hoje também a ser estudadas como resultado de um processo social; de um processo organizacional. Além disso, o estudo das metáforas tem possibilitado apreender as organizações como polifonias, como um conjunto de diversas imagens e histórias.

Para a concretização deste trabalho, foram realizadas aproximadamente 100 entrevistas com pessoas que trabalham ou trabalharam na empresa estudada. No rol dos entrevistados aparecem 45 gerentes, 40 técnicos, 2 ex-presidentes, 2 sindicalistas, 9 ex- 
empregados. Para isto, elaboraram-se três roteiros de entrevistas: o primeiro roteiro foi estruturado de maneira a possibilitar a contextualização da pesquisa; trata-se de um roteiro básico a ser empregado nas entrevistas com os diretores e assessores da diretoria, tanto da holding, da organização objeto desta pesquisa, quanto da diretoria do sindicato. O segundo roteiro foi utilizado para os gerentes de todos os níveis. Já o terceiro roteiro foi base para as entrevistas com os demais empregados e ex-empregados. Neste estudo qualitativo usou-se nas entrevistas semi-estruturadas para a coleta de informações somente um roteiro de apoio, de forma a possibilitar maior flexibilidade no tratamento das questões, na medida em que se tornassem relevantes para o estudo, como, por exemplo, aspectos da história de vida dos atores envolvidos. Segundo THIOLLENT (1987), as entrevistas semi-estruturadas são estratégias capazes de introduzir o pesquisador no universo cultural dos indivíduos. Deve-se também destacar que foram coletados documentos da empresa: Relatórios Anuais, DDdicas, Jornal Telemar, Construindo a Transformação, entre outros; e do sindicato: O Bode Berra, O Bodim Semanal, etc, que se relacionavam à história da empresa dos fins dos anos oitenta até o começo do novo milênio.

As narrativas elaboradas pelos entrevistados revelavam a articulação entre as metáforas e as identidades organizacionais. Coube, então, ao pesquisador buscar identificar as metáforas usadas nos discursos organizacionais, pois era através delas que ocorria a materialização das velhas e novas identidades, dos desejos, das explicações, das justificativas e racionalizações existentes na formação social e organizacional em que os indivíduos estavam inseridos. Destaca-se que a empresa era identificada sempre através de metáforas que traduzem uma visão da organização, uma visão de mundo (MANGHAM, 1996).

Deve-se ainda ressaltar, que as narrativas aqui analisadas foram produzidas à medida em que este estudo procurou resgatar um processo histórico que remonta ao começo da década, com base em informações coletadas a posteriori em julho de 2000. Nesse sentido, as informações colhidas nas entrevistas emergem de reflexões dos atores organizacionais, podendo-se perceber, inclusive, uma certa nostalgia do momento anterior a privatização e uma certa ambigüidade nos fragmentos discursivos referentes às novas identidades que estariam sendo construídas.

\section{AS IDENTIDADES DA ORGANIZAÇÃO}

Quando a Telemig tornou-se parte da Telebrás, em 1973, ela incorporou outras 100 companhias no Estado de Minas Gerais. Seu primeiro plano estratégico envolveu a extensão 
dos serviços ao interior do Estado, integrando mais de duzentas cidades sem conexões telefônicas e as companhias adquiridas em uma única holding. A identidade da Telemig foi construída em torno da missão de fornecer serviços de telecomunicações para todas as partes do Estado, até mesmo as mais remotas. Durante o período de 1990 até 1995, observou-se inúmeras mudanças significativas - como o projeto qualidade e o da reengenharia - que contribuíram para a modificação da identidade da empresa no sentido da provisão de serviços, isto é, na mudança de uma empresa de engenharia para uma companhia de serviço. Na fase denominada de pré-privatização, que vai de julho de 1995 até julho de 1998, assume uma nova diretoria indicada pelos governos federal e estadual. Essa nova diretoria busca implementar e aprofundar algumas transformações para tornar a TELEMIG mais rentável e, portanto, mais interessante para possíveis novos proprietários. Usa-se o "terreno arado" (metáfora colhida na entrevista com um diretor) e busca-se aprofundar e institucionalizar a identidade, para definitivamente transformar a TELEMIG em uma empresa de negócios de telecomunicações. Por fim, quando em junho de 1998 ocorreu a privatização, a companhia teve que aprender novas formas de relacionar-se no mercado; o foco no cliente ficou mais intenso, apesar de todas as preparações nesta direção antes de privatização. Na verdade, após julho de 1998 a Telemig transformava-se em Telemar.

No Quadro 1, pode-se observar as principais metáforas usadas na identificação da empresa pelos atores organizacionais. O quadro refere-se às metáforas de identidade usadas mais constantemente pelos grupos de pessoas entrevistadas. Além disso, pode-se perceber duas divisões claras, uma quando a empresa ainda era pública - Telemig (antes de julho de 1998) - e outra quando já havia sido privatizada (depois de julho de 1998).

\begin{tabular}{|c|c|c|}
\hline & Antes privatização - Telemig & Depois privatização - Telemar-Minas \\
\hline Diretorias & A (operadora de serviço e gestão) $\mathrm{n}^{\mathbf{o}} 1$ & a (filial) referência \\
\hline Gerentes & a grande família & a vaca leiteira \\
\hline Técnicos & a mãe & a madrasta \\
\hline Sindicato & a caverna & a pecadora \\
\hline
\end{tabular}

QUADRO 1: Metáforas de Identidade

FONTE: Dados da Pesquisa

\subsection{A Identidade para os Atores Organizacionais quando Telemig}

Os discursos explorados internamente pelas diretorias ${ }^{\mathrm{iii}}$ antes da privatização revelamse integrados e voltados para determinados objetivos e valores que fomentassem uma união em prol da gestão da empresa Para essas diretorias da empresa, a Telemig poderia ser descrita 
ou identificada como a "Número 1" do Sistema Telebrás. Muitas das principais estratégias traçadas pela alta administração reforçam essa metáfora de ser a primeira do Brasil

"A Telemig promete: Vai ser a número 1".(Construindo a Transformação, 1995).

As estratégias elaboradas por essas diretorias para concretizar a imagem de ser a primeira do Brasil aparecem em várias práticas gerenciais como foi a implantação do projeto qualidade total que levaria a uma reengenharia e uma profunda reestruturação da Telemig. Ao mesmo tempo, as diretorias procuram tornar-se forte o bastante para usar de todos os esforços na concretização da transformação da identidade por ela mesma idealizada - de ser a número 1 do país -, buscando também enfatizar a liderança gerencial da empresa frente ao sistema Telebrás. Pode-se destacar que no fundo dessa metáfora, criada para promover uma identificação positiva da empresa para com seus empregados e para com a sociedade, estava uma outra mudança de identidade elaborada pela alta administração: a transformação de uma empresa de telefonia em uma empresa gestora de serviços de telefonia. O discurso reiterava freqüentemente que:

"Essa transformação é essencial para a sobrevivência da Telemig" (Linha Direta, dez. 1994).

A imagem que a alta administração busca passar é a de uma empresa em processo de adequação aos novos tempos, que exigem das organizações flexibilidade, baixos custos, lucratividade e agilidade. Através de uma gestão criativa, como afirmado no Relatório Anual, a administração da Telemig se propôs conseguir a modernização da empresa. E, para isso, empenhou-se no sentido de sustentar a prestação de serviços e aprimorar os processos de atendimento aos clientes, a partir de um "novo olhar" sobre as demandas do mercado:

"Na verdade, somos uma empresa prestadora de serviços de telecomunicações. Temos que nos preocupar com o mercado, com marketing, com vendas, com atendimento (...) " (Construindo a Transformação, 1995).

"De identidade introvertida, voltada para ela mesma, para a engenharia, a técnica... para uma identidade extrovertida, de liderança, voltada mais para o mundo, para fora... para os clientes" (ex-diretor).

Grande parte das narrativas colhidas retratam indiretamente os objetivos estratégicos de transformar a empresa (de engenharia) em uma organização prestadora de serviços. Os discursos elaborados pela alta administração reforçam sempre a metáfora da Telemig ser a empresa número 1 de serviços de telecomunicações do Brasil. Essa mudança de identidade é 
tida como vital para a sobrevivência empresarial na década de 90 e para a manutenção das diretorias no poder, uma vez que sugere sincronia entre Governo e dretorias da empresa, em termos de discursos e ações.

Para os gerentes, a metáfora de identidade da empresa, nesse período anterior a privatização, era a da "grande família". Para alguns gerentes, as mudança impostas pela alta administração não se processaram de foram simples, como buscou a alta administração aparentar em seu discurso. A era Collor é vista como uma época traumatizante para a empresa, seus empregados, enfim, para a família Telemig:

"A empresa, naquela época, era uma empresa principalmente familiar. No Plano Collor, houve um "ajuste" do quadro de pessoal, "ajuste" esse que, na minha opinião pessoal, foi traumatizante. Foi o segundo grande "ajuste" de pessoal." (ex-Gerente 1).

“Logo no princípio de 90, com o Collor, a Telemig teve o primeiro trauma, com a demissão em massa, coisa que nunca tinha acontecido na Telemig. Nós tivemos uma demissão... então nós começamos a aprender que existia isso, que a organização não era familiar, não era só familiar." (Gerente 37).

As demissões ocorridas nos anos noventa, eufemisticamente denominadas de "ajuste do quadro de pessoal", foram, no entender desses gerentes, traumáticas para a empresa. O mito da família Telemig e o tema da estabilidade no emprego, de uma só vez, foram ameaçados. Mas, essa identidade - de ser uma família - foi construída com o passar da história da empresa e, portanto, fortemente arraigada a visão de mundo desses atores.

"A Telemig tem uma característica: isso aqui é uma grande família. (...) Porque aqui você encontra desde neto até avô trabalhando aqui dentro. Muitas pessoas se casaram aqui dentro, namoraram, casaram, separaram, têm filho, casaram de novo aqui dentro mesmo. Então aqui você encontra parente de tudo quanto é jeito. (...) Aqui, antigamente, quando se ganhava bem, saíam as famílias para passear na praia, ficavam um mês na praia juntas; três, quatro famílias alugavam uma casa na praia e ficavam lá o tempo todo ..." (Gerente 19)

"Eu me entusiasmei com a empresa, tenho um apego enorme a ela, não só porque aqui eu construí minha vida profissional, mas também porque tive a oportunidade de construir um círculo de amizades." (Gerente 43).

O indivíduo que entrava na empresa sabia que era para toda a sua vida. Suas amizades seriam construídas basicamente com as pessoas com quem se relacionava grande parte do dia, e sua formação profissional voltava-se para contemplar as necessidades da empresa. Os temas que reportam à metáfora da grande família enaltecem a Telemig, sua criatividade, seu pioneirismo, sua vanguarda em face das atras Teles do Sistema Telebrás. Havia respeito aos empregados; havia garantia de permanência no emprego. A aproximação entre a gerência e os 
empregados era facilitada pela identidade da organização - de uma grande família. Segundo RODRIGUES (1991: 145), “o mito da família Telemig não tem um significado único, representa desde uma subdivisão de relações estabelecidas por parentesco ou amizade, até um modo de estabelecer prioridades e hierarquias nos interesses e lealdades grupais". Ainda segundo essa autora, as significações trazem o desejo de um tratamento igual, ou seja, a família deve dispensar tratamento igualitário a todos os seus protegidos, independentemente das condições de cada um. Tal desejo, na realidade, não se concretizava, pois, como já foi dito, havia disputas entre grupos, com relação à área de conhecimento mais importante para a empresa.

Para os técnicos, semelhantemente aos gerentes, a metáfora que predomina antes da privatização e que mostra, além da identificação com a empresa, certa coesão interna nesse grupo, é o da grande família ou, mais precisamente, a da mãe:

"Como falei no início, a Telemig era estatal, voltada assim mais para o funcionário. Era muito familiar." (Técnico 13).

"Uma mãe. uma mãe mesmo" (Técnico 23).

"Na Telemig, a gente conseguiu tudo. Se a gente tem casa, conseguiu pela Telemig. Tinha bons salários, era uma firma, era uma empresa bem mais estruturada... Ela se preocupava com 0 funcionário, como se ela tivesse mais tempo de se preocupar com o funcionário. É como se fosse uma mãe mesmo, que não trabalha fora, preocupando-se mais com o filho; a mãe que trabalha fora já dispensa menos atenção, porque não dá tempo realmente, não é?" (Técnico 21).

"vamos dizer que ela foi sempre uma grande mãe, uma mãezona para gente." (Técnico 33).

A imagem da empresa como mãe que protegia, amparava, sustentava e diferenciava foi evocada com surpreendente incidência. A identificação entre empresa e empregado era muito forte. A Telemig, sendo uma empresa pública, dava segurança, estabilidade e benefícios que produziam uma diferenciação no ambiente fora da empresa. Era o mundo Telemig. As pessoas que fizeram parte desse grupo de técnicos sentem-se gratas por terem trabalhado nessa empresa que lhes deu status em termos sociais, lhes deu uma identificação diferenciada em relação aos demais empregados. Assim, seja a empresa vista como mãe, seja como família, em termos de significação cultural essas metáforas estão ligadas às relações internas construídas historicamente por essas pessoas que se sentiam como os profissionais que realmente operacionalizavam a Telemig.

A identidade da Telemig para o Sindicato é fortemente representada pela metáfora da empresa como caverna. Está metáfora surge ligada a um novo personagem apresentado nos 
jornais do sindicato - O Bodim - a partir de 1994. Esse personagem é denominado Quem, eu?":

“Esse personagem, (...) um cara com um olho, numa caverna escura, em que só aparecia o olho. Sabe, resgatei isso. Falei: mas é isso, se eu não sei desenhar, o meu personagem é o olho dentro da caverna. Então era isso. Era um... personagem reflexivo... 0 objetivo era botar a categoria dentro da caverna, observando o mundo, o que acontecia lá" (Sindicalista e criador da personagem).

O personagem principal da tira é muitas vezes representado somente por dois olhos - ora grandes, ora pequenos -, outras vezes também aparece uma boca e, em outras, ainda as mãos. Segundo o próprio criador do personagem, 'Quem, eu?' representava a categoria dos trabalhadores em telecomunicações, dentro de sua caverna, seguros de si, de seus empregos, de suas vidas, enquanto o mundo acontecia lá fora. Uma categoria sem rosto! Pode também significar uma visão do próprio sindicato, que via a categoria sem uma face definida, sem uma identidade que, no fundo, representasse alguma escolha, seja de uma determinada visão de mundo, de uma cultura, de uma identidade, de valores que, supostamente, o sindicato estaria oferecendo. O nome da personagem é elucidativo: Quem é um pronome interrogativo referente à pessoa. Ao mesmo tempo, a expressão Quem, eu? parece significar que a pessoa não quer ser referida, buscando ausentar-se. Dessa forma, sugere que a categoria era chamada pelo sindicato a manifestar-se, a identificar-se, pois era vista como querendo ausentar-se, não se mobilizar, assistindo a tudo 'alienada' do processo histórico pelo qual passava o país fechada na caverna (FIG. 1). Muitas vezes, aceitando a visão de mundo construída pela alta administração da empresa sem nenhuma resistência.
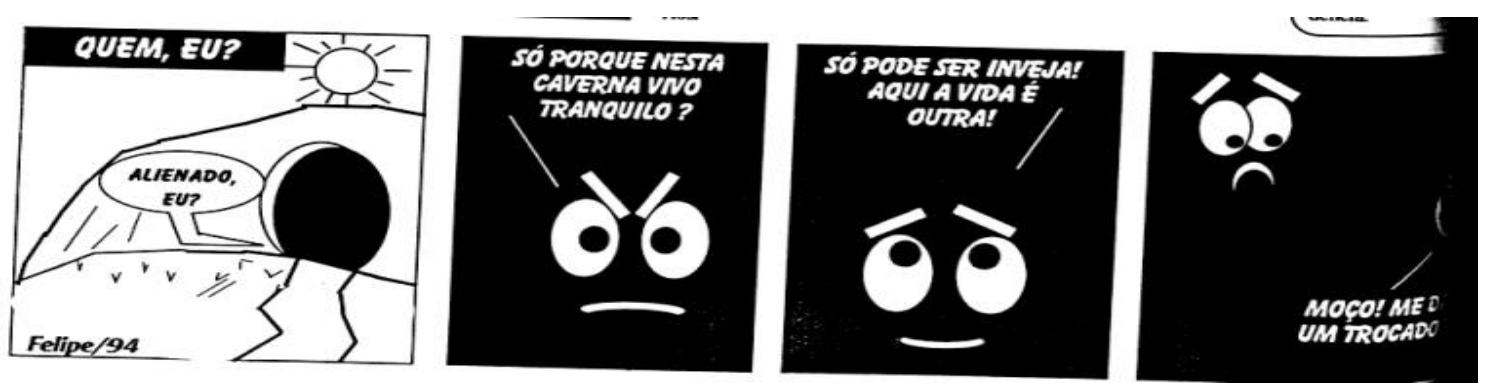

FIGURA 1: 'Quem, eu?' na caverna FONTE: Bodim, março 1994,
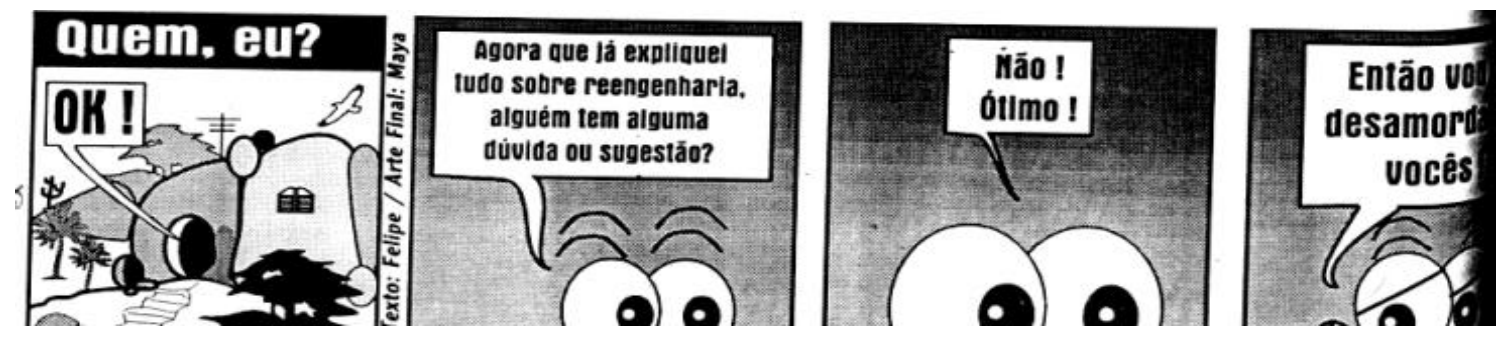
FIGURA 2: ‘Quem, eu?' e a reengenharia 1

FONTE: Bodim, junho 1994
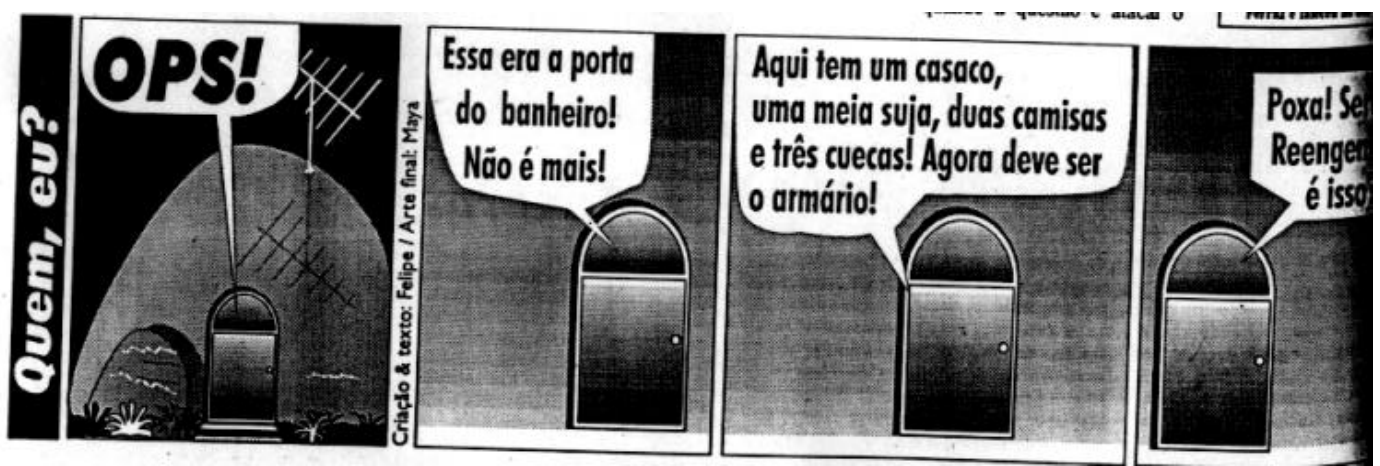

FIGURA 3: 'Quem, eu?' e a reengenharia 2

FONTE: Bodim, julho 1994

Conforme está retratado na primeira tira, o discurso dirige-se diretamente aos trabalhadores. A sátira dos quadrinhos remete ao tema da alienação. Durante a década, este será um dos grandes temas explorados pelo grupo do sindicato: a alienação no sentido da nãoparticipação, não-movimentação contra as decisões que vinham de cima - diretoria da empresa e governo. Ao mesmo tempo, havia um projeto desse grupo no sentido de fazer um sindicato cidadão, preocupado com os temas importantes para a sociedade. A personagem desenhada dentro de uma caverna representa a categoria dos trabalhadores em telecomunicações, seguros em suas empresas, em seus empregos, com seus salários.

A segunda tira apresentada mostra que a proposta de reengenharia foi imposta, sem que fosse possível diálogo algum. Não houve nenhuma possibilidade de participação real dos trabalhadores sobre essa prática na empresa. A terceira tira mostra que a proposta de reengenharia elaborada estaria apenas mudando as coisas de lugar, mas a caverna continuava a mesma, ou seja, a estrutura interna da organização não estaria sendo alterada. Para o sindicato, isto seria a reengenharia proposta: propunham-se mudanças, mas tudo no final permaneceria como era antes, as significações atribuídas pelos dirigentes ao trabalho e aos empregados continuariam as mesmas.

De maneira o grupo representado pelo sindicato buscava desmascarar as estratégias elaboradas pela alta administração, principalmente pelo humor e pela ironia, bem como 
apontar a participação dos gerentes nesse processo de transformação da TELEMIG em uma empresa que serviria, aos poucos, a grandes clientes. Essa estratégia paulatinamente intensificará suas metáforas de resistência, mostrando que a privatização não será somente uma perda para os empregados da TELEMIG, mas para a sociedade como um todo.

\subsection{A Identidade para os Atores Organizacionais quando Telemar-Minas}

Para a diretoria que assumiu a empresa após a sua privatização pode-se observar o uso quase que constante de uma metáfora: "a referência" para descrever a Telemig e seu papel na nova holding formada.

"A Telemig sempre foi considerada uma empresa padrão dentro do antigo Sistema Telebrás" (Relatório Anual, 1998).

O destaque é dado à Telemig, como uma empresa de referência, sendo-lhe atribuída o papel de liderança à integração com outras operadoras da nova holding como, por exemplo, a Telest do Espírito Santo. Evidencia-se o tema do intercâmbio de cultura e processos como facilitadores da união entre ambas. Para os dirigentes da empresa mineira, assumir a Telest é passar-lhe a "personalidade" da Telemig que é, por sua vez, a da própria diretoria mineira. Somente assim, segundo a alta administração mineira, é que a empresa capixaba conseguirá atingir os mesmos níveis da mineira:

“Estamos assumindo agora o Espírito Santo. Nós estamos passando para eles a nossa personalidade Telemig. Eles já estão assumindo os nossos resultados e nós estamos incorporando a empresa de uma forma gradativa, com dor, claro. Você não faz mudança sem dor".(Diretor)

Os dirigentes da Telemig, ao assumirem a empresa capixaba, impuseram-lhe sua maneira de ver o mundo dos negócios de telecomunicações, passando-lhe o que eles denominaram de "personalidade". Com dor, eufemismo para demissões, busca-se mudar a identidade da Telest, para que ela passe a ser quase mineira.

" 'A Telemig é espetacular, é o grande centro de excelência de toda a holding'. Segundo ele [Vice-Presidente da Tele Norte-Leste Participações], os funcionários são a parte mais importante do empresa, e agora terão a seu lado um grupo arrojado (a Construtora Andrade Gutierrez), (...). 'Isso vai ajudar aqui dentro da Telemig e saibam que, entre os sócios da Tele Norte-Leste não existe nenhum mais ou menos bom, todos são líderes" (DDdicas, ago 1998). 
Não são poupados elogios à Telemig, a seus empregados e aos próprios proprietários, estes últimos definidos como líderes em suas atividades. Na verdade, era preciso mostrá-los como bons, os melhores em suas atividades, bem como exaltar a administração de suas empresas, pois era necessário justificar a falta de uma operadora, de um gestor com experiência no negócio das telecomunicações. Para isso, recorre-se a todo o momento a empresas como a Telemig, que se sobressai como operadora referência pela excelência dos serviços prestados. É importante evidenciar que se em muitos fragmentos discursivos pode-se observar a exaltação à Telemig, como a empresa líder da nova holding privada, há estratégias escolhidas pela nova diretoria que acabam mostrando para os atores organizacionais envolvidos que essa importância não ocorria. Vale destacar duas estratégias. A primeira é sobre a localização da matriz - a Telemar - e a segunda, recaí sobre escolha do novo nome.

"matriz do grupo que funciona no Rio de J aneiro. É composta de uma Diretoria Executiva e tem o Conselho de Administração, acima dessa Diretoria Executiva" (Diretor).

"a grande tendência é criar um empresa única, cuja matriz será no Rio de J aneiro, e as demais empresas vão se constituir em filiais ligadas a alguns núcleos centrais. (Diretor)".

A partir desse momento o vocábulo "filial" é continuadamente mencionado nos discursos da diretoria da empresa. Na verdade, mais do que isso é revelado: fala-se da estratégia que se delineia na matriz no Rio de Janeiro, no sentido de transformar as empresas como a Telemig em filiais de vendas e manutenção. Neste plano de aprofundamento da transformação da identidade, estaria a metamorfose da Telemig em Telemar-Minas:

" 'A Tele Norte-Leste nascia em julho de 98, representando 16 empresas do Sistema Telebrás. Hoje, estamos lançando o nome dessa nova empresa, Ontem, éramos 16 operadoras, hoje, somos uma única empresa, a Telemar, com Unidades de Negócios em 16 Estados e escritórios comerciais em outros três. (...) ' " (DDdicas, março/abril 1999).

Essas duas estratégias oportunizaram o aparecimento na empresa de um forte sentimento de frustração entre os empregados, o que gera aos poucos temas que apontam uma possível resistência às decisões e ações da matriz, como no caso da mudança de nome da empresa:

"Volto a frisar o caso Telemig. É estranho... a gente é até objeto de brincadeira dos outros. É Telemar, mas aqui não tem mar, quer dizer, a Telemig está fora do processo. Então eu acho que não se identifica conosco. 0 nome não se identifica com a Telemig, mesmo porque Telemar foi colocado por causa da grande parte litorânea que a empresa ocupa. E Telemig está fora do litoral, então ela estaria fora da marca, não é?" (Gerente 33). 
"Não foi do agrado do pessoal. Eles sabiam que teriam que mudar o nome, (...), mas principalmente acho que a maior frustração foi não ter a sede da empresa aqui. Então, esse nome 'Telemar' foi muito doloroso para os mineiros, único Estado que não tem mar. Acho que tem outro lá em cima que também não tem mar, mas nós nos consideramos o único que não tem mar, e o poder tinha sido transferido para onde tem o mar" (Técnico 13).

A proposta de mudança do nome e da criação da matriz no Rio de Janeiro fez com que muitos dos empregados da Telemig construíssem para a empresa metáforas que evidenciam certo ressentimento para com a transferência do poder de decisão, perda de autonomia e de benefícios conquistados através da história da empresa enquanto operadora pública.

Quando ocorre a privatização e a Telemig é ao poucos transformada em filial, a "grande família" dos gerentes começa a ser, concretamente, desmontada:

"Nós estamos deixando de ser a Telemig para ser apenas uma filial. Estamos deixando de ser uma grande família... é isso que nós estamos vivendo hoje." (Gerente 15).

No entanto, a Telemig continua sendo vista como a operadora que referencia os trabalhos da Telemar:

"A Telemig tem sido referencial para todo esse trabalho de unificação das dezesseis empresas, mas realmente tem que refrear um pouquinho, para poder todo mundo se encontrar, não é? (...) A gente está sempre ouvindo esse comentário na mídia ou direto dos clientes, de que houve uma quebra de Telemig para Telemar." (Gerente 20).

Nesse processo de unificação das dezesseis operadoras públicas estaduais em uma holding privada desenvolveu-se a metáfora da vaca leiteira:

'você vai ver que nós somos, no caso, a 'vaca leiteira'. Nós aqui estamos dando material para todo mundo poder trabalhar, para ver se conserta um abacaxi igual ao do Rio de J aneiro e outras coisas... é difícil..." (Gerente 39).

“... nos causa ainda um certo desconforto (...) nós somos apenas uma vaca leiteira para essa holding e isso chegou a causar até um certo ciúme. A quantidade e qualidade dos profissionais Telemig exporta é enorme..." (Gerente 32).

A Telemar-Minas passa a ser vista então como a empresa que nutre as demais da holding. E essa nutrição - leite e carne - ocorre tanto pelo fornecimento de pessoas como de conhecimento tecnológico, para as outras operadoras.

A unificação das dezesseis empresas em uma só operadora parece ser vista por alguns entrevistados como um momento de transição, mas também como um momento em que a 
melhor empresa da holding - a Telemig - estaria sendo sacrificada. Como a melhor "vaca leiteira", a empresa é sempre "ordenhada" e seu leite distribuído pela holding. Por trás dessa metáfora, há um tema importante, o da mineirização da Telemar, ou seja, a emigração dos mineiros, funcionários da Telemig, que levariam seus conhecimentos para os outros e por toda a holding. Mais precisamente, estaria havendo também uma mineirização da alta administração da Telemar como um todo. Em um caso mais particular, o grupo que exerceu a última diretoria da Telemig é que migrou para postos-chave no Rio de Janeiro:

“... essas pessoas hoje já saíram da empresa, todas elas... Esse grupo todo, hoje, atua no Rio, na Telerj, na Telemar-Rio. Está tudo lá... Era um grupo muito unido. Eles conduziram o processo de reengenharia e a privatização e, com a privatização, eles saíram da Telemig".(Gerente 14)

"Existe hoje também um arranhão em relação à auto-estima de parte dos profissionais, porque houve um enxugamento de recursos gerenciais para a matriz no Rio de Janeiro e, consequentemente, as pessoas se ressentiram em dois aspectos: um porque dizem que nós perdemos as nossas melhores cabeças gerenciais, e os gerentes que ficaram têm um certo ressentimento no sentido de que foram preteridos: 'Eu não fui escolhido para estar lá.' Então existe essa ambigüidade. Ao mesmo tempo, existe um certo alívio geral das pessoas que ficaram, porque é uma mudança radical: mudar de cidade, mudar a família, mudar de casa, mudar o filho de escola, essa coisa toda. Então esse é um dilema que o gerente vive hoje. Então, ele sente sua auto-estima um tanto reduzida com relação a estes aspectos." (Gerente 13).

O fragmento mostra uma certa ambigüidade na mineirização da matriz. Apesar disso possivelmente significar algum orgulho, no sentido de ganho de espaço e poder dos mineiros, apesar da transformação da ex-Telemig em filial, para os gerentes que permaneceram na empresa existem outros sentidos: um é o sentimento de que foram preteridos, por não corresponderem ao perfil desejado pela matriz; outro é a desconfiança de que, permanecendo na filial, não ascenderiam hierarquicamente na holding, embora essa permanência lhes trouxesse algum sentimento de alívio, pois ir para o Rio de Janeiro seria mudança radical e corte de muitas raízes fortemente estabelecidas em Belo Horizonte.

Para os técnicos, após a privatização, a metáfora que vai predominar é outra contrária a da mãe. As ambigüidades do discurso e das ações da alta administração, por não conseguir sequer esclarecer qual é a missão da empresa, qual é sua nova identidade, gera falas desta natureza:

"A gente está massificado, massacrado... Temos trabalhado, o nosso horário é de, no mínimo, dez horas por dia, o pessoal tem feito é dez, doze horas, quando não tem virado a noite." (Técnico 1).

"A gente está realmente numa postura de anticlímax; estamos aguardando realmente para ver 0 que acontece. (...) 0 stress aumentou por causa exatamente da concorrência. Já não estamos trabalhando com tanto prazer." (Técnico 12). 
“... é uma loucura esse negócio..." (Técnico 22).

"A gente passa aqui mais de oito horas... dá o sangue... Não são só oito, não, é? Nós passamos aqui atualmente tipo doze, ninguém vai embora. Você chega aqui embaixo, no estacionamento, oito e meia da noite é como se fossem três horas da tarde. Está todo mundo aí. Os gerentes não vão embora antes de dez, e a gente é obrigado a ficar também. Eu não sei até quando isso vai poder ficar assim." (Técnico 13).

O massacre, o aumento de stress, as exigências, as horas de trabalho, a dedicação fazem com que o que antes era prazeroso - trabalhar na Telemig - se torne na Telemar-Minas uma loucura, um anticlímax, criando entre os técnicos forte sentimento de insegurança e medo. O grupo dos técnicos é consensual no entendimento de que a empresa tinha no passado uma identidade que estava associada a valores tais como: grupais, ligados à coletividade; incentivando o saber técnico e o desenvolvimento de seus empregados. Alguns técnicos, lamentando a perda de identificação, externaram negação em 'vestir a camisa' e insistiam na constante comparação entre a Telemig e a Telemar-Minas. Para esses técnicos, a mudança para Telemar foi e tem sido um complexo ritual de passagem, que tem transformado uma empresa "Mãe" em uma "Madrasta". A maioria dos empregados entrevistados diz que, no dia da mudança nome da empresa, enterrou, de vez, a mãe:

"A história mudou. A Telemig morreu mesmo. No início, tivemos que colocar uma tarja preta no nosso crachá. Olha, eu confesso, na hora doeu, disso não tenha dúvida. Teve colega que cobriu 0 nome com uma tarja, até os novos crachás ficarem prontos. Mas você ainda vai ver muita gente que ainda tem esse crachá coberto, como sinal de luto, entendeu?" (Técnico 13).

No lugar dessa mãe, foi se instalando uma outra empresa, que não tem conseguido mostrar para que veio, instaurando sentimentos de ansiedade e insegurança por todo o grupo. Havia ainda alguma expectativa de que a nova empresa continuasse a ser uma mãe, embora mais rígida e preocupada com o desempenho, com o lucro, mas que garantisse, senão alguma estabilidade, pelo menos muitos dos benefícios historicamente conquistados pela categoria. A Telemar, seus proprietários e administradores, contudo, mostraram-se, para os técnicos, ambíguos, ora falando da importância da Telemar-Minas, ora fazendo do Rio de Janeiro o Estado sede da holding e levando muitos dos empregados para outros estados, ora exaltando seus funcionários, que agora deveriam ser considerados colaboradores, ora reduzindo seus benefícios, ora limitando sua autonomia e aumentando o controle, ora pagando mais pelo desempenho. Assim, para os técnicos, em sua maioria, a nova empresa estaria se transformando em uma madrasta: 
"A Telemar está mais parecendo uma madrasta, muito diferente da mãe que era a Telemig." (Técnico 4).

"Eu não gostei não (...) Nós perdemos a mãe, e você sabe qual é o sentimento de perder a mãe?" (Técnico 16).

"Um familiar, não é? A mãe... Muita gente se sente desamparada aqui... é o sentimento" (Técnico 20).

"Telemig, aquilo que era uma maravilha. Agora o que existe no lugar é a TELEMÁ! " (Técnico $11)$.

A "madrasta", a "TELEMÁ" no dizer do técnico ao se referir a Telemar-Minas, oposta à Telemig mãe, parece não oferecer a seus "enteados" muitos horizontes. A falta de horizontes, de clareza da matriz quanto às metas da empresa, parece levar para um grupo significativo dos técnicos ouvidos a um retrocesso histórico. O retrocesso, para esses técnicos, está muito calcado em ações, em fatos reais e concretos que os atingem em seu dia-a-dia na empresa. Todavia, um entrevistado conseguiu realmente mostrar a importância do tema retrocesso reportando-se à época dos militares, em que um forte controle sobre os empregados técnicos vigorava:

"O objetivo que nós estamos vendo aqui é único. Tem um discurso de que está tudo bem, mas não está tudo bem. Eu que transito muito por aí, eu sei que não está bem. Realmente, lamentavelmente, está havendo uma regressão nos processos. Vamos voltar para a época dos militares, só que sem aquele laço familiar que unia a gente, sem aquele 'vestir a camisa', sem aquela identidade, não é?" (Técnico 11).

Com um sentido semelhante, a metáfora que começa a aparecer nos fragmentos discursivos do grupo do sindicato, quando a Telemig é privatizada, é a da empresa pecadora, que surge como resposta a campanha realizada pela alta administração da empresa de mostrar o sindicato como "o grande mal", responsável pelo atraso nas negociações coletivas e assinaturas dos Acordos Coletivos. A alta administração da empresa, segundo o sindicato, procurou combater.

"A questão do sindicato. Ele como o grande mal, e olha que a Telemar tem se esforçado um bocado para isso." (Sindicalista).

Mas se a alta administração desenvolveu a alegoria do sindicato como "o grande mal", este não deixou por menos, e criou a metáfora da empresa como "grande pecadora". Utilizando-se dos sete pecados capitais, um tema religioso, buscou criar uma imagem da Telemar como a empresa que nada respeita, somente voltada para o lucro. Na concretização dessa estratégia, usou-se para cada pecado uma figura (FIG. 3), uma simbologia, um tema: 
"Os 7 pecados capitais da proposta da TELEMIG.

1. A avareza é a mãe da miséria: Oferecer reajuste ZERO para os trabalhadores, enquanto a produtividade e a lucratividade da empresa crescem absurdamente, graças ao esforço e competência de seus empregados. Ainda reduzir nossos adicionais por tempo de serviço, horas extras, sobreaviso, além da redução da gratificação de férias, de 70\% para 33\%. A avareza da Tele parece não ter limites: pretende ACABAR com o anuênio e qüinqüênio.

2. A gula está devorando os empregos: Em um país onde as taxas de desemprego batem recordes, a TELEMIG ajuda a engrossar as tristes estatísticas produzidas pelo Brasil, demitindo mais de 1.300 empregados

3. Queremos saúde de dar inveja: Saúde de dar inveja. Esse é um dos lemas de nossa campanha salarial. Sabe o que a TELEMIG quer fazer com a saúde dos trabalhadores? Destruir todos os mecanismos de proteção de nossa saúde. A Tele quer sumir com todas as cláusulas relativas à CIPA e ainda pretende retirar o Telemed de suas normas internas, abrindo caminho para uma futura extinção do plano.

4. Negociar é abdicar da soberba: Quem está disposto a negociar de verdade deve abdicar da soberba. Não é isso o que a empresa vem demonstrando ao oferecer uma proposta como a que aí está. Quem deseja estabelecer relações modernas com seus empregados deve, em primeiro lugar, tratá-los com respeito e transparência.

5. Quem não reconhece a preguiça merece recompensa: Mesmo o setor de telecomunicações estando em alta, com perspectiva de crescimento, a empresa demitiu mais de 1.300 trabalhadores, vindo a sobrecarregar mais os que ficaram, que têm que dar conta de todo 0 serviço. 0 resultado é um número elevado de horas extras. A Tele agora propõe pagar o limite legal para a hora extra, ou seja, $50 \%$, ao invés dos $100 \%$ praticados hoje.

6. 0 prazer de explorar é a pior luxúria: Propor ao trabalhador manter as 40 horas como é hoje, mas permitindo à empresa, quando quiser, exercitar a jornada de 44 horas. Isso não tem outro nome senão EXPLORAÇÃO. Nessa mesma linha, a TELEMIG tirou da cartola o banco de horas, onde a compensação vai depender da boa vontade da empresa.

7. Medieval não é o sindicato, mas a ira é contra ele: Medieval é a ira contra o Sindicato. A empresa tentar enfraquecer a representação dos trabalhadores, reduzindo o número de dirigentes liberados que defendem os direitos dos empregados." (Bodim, dez. 1998) ${ }^{\mathrm{iv}}$
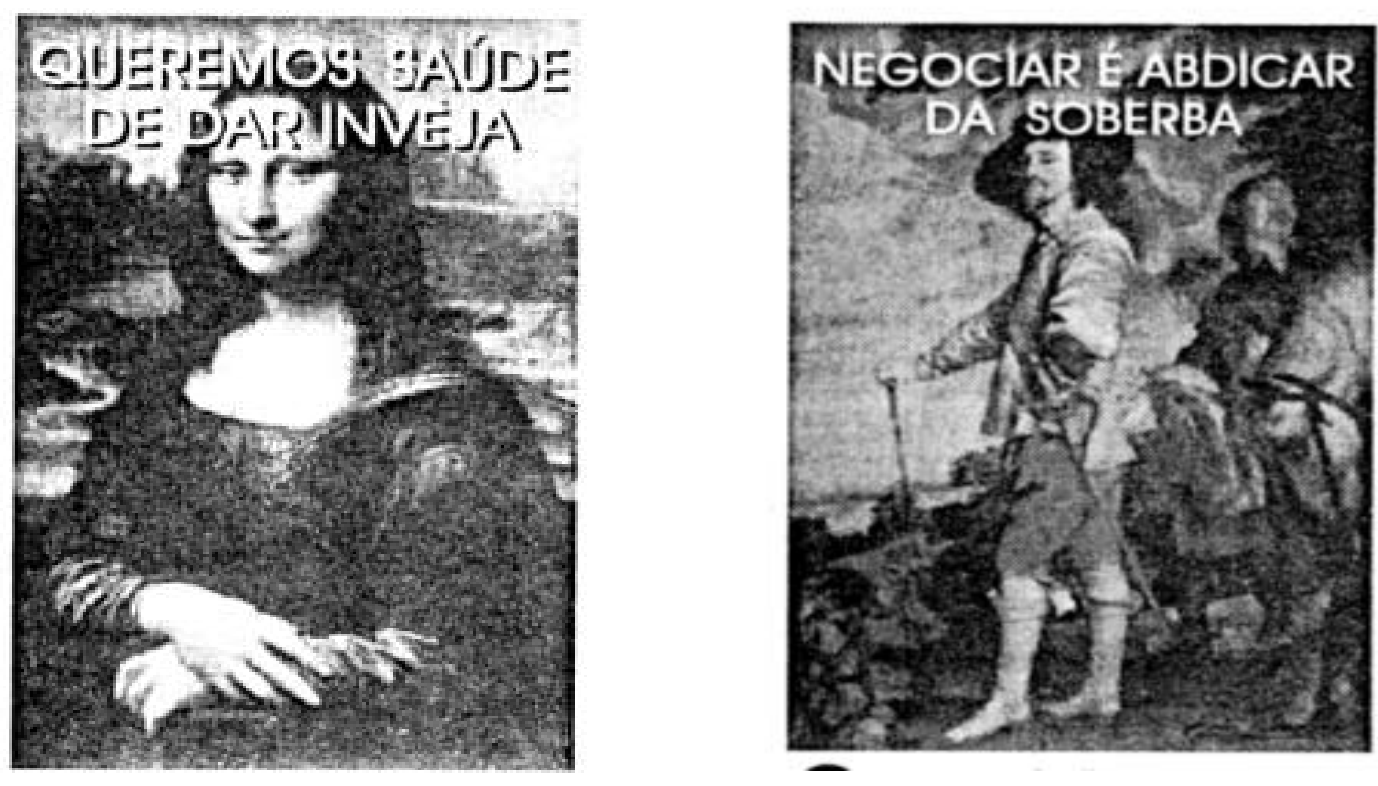
mujo.
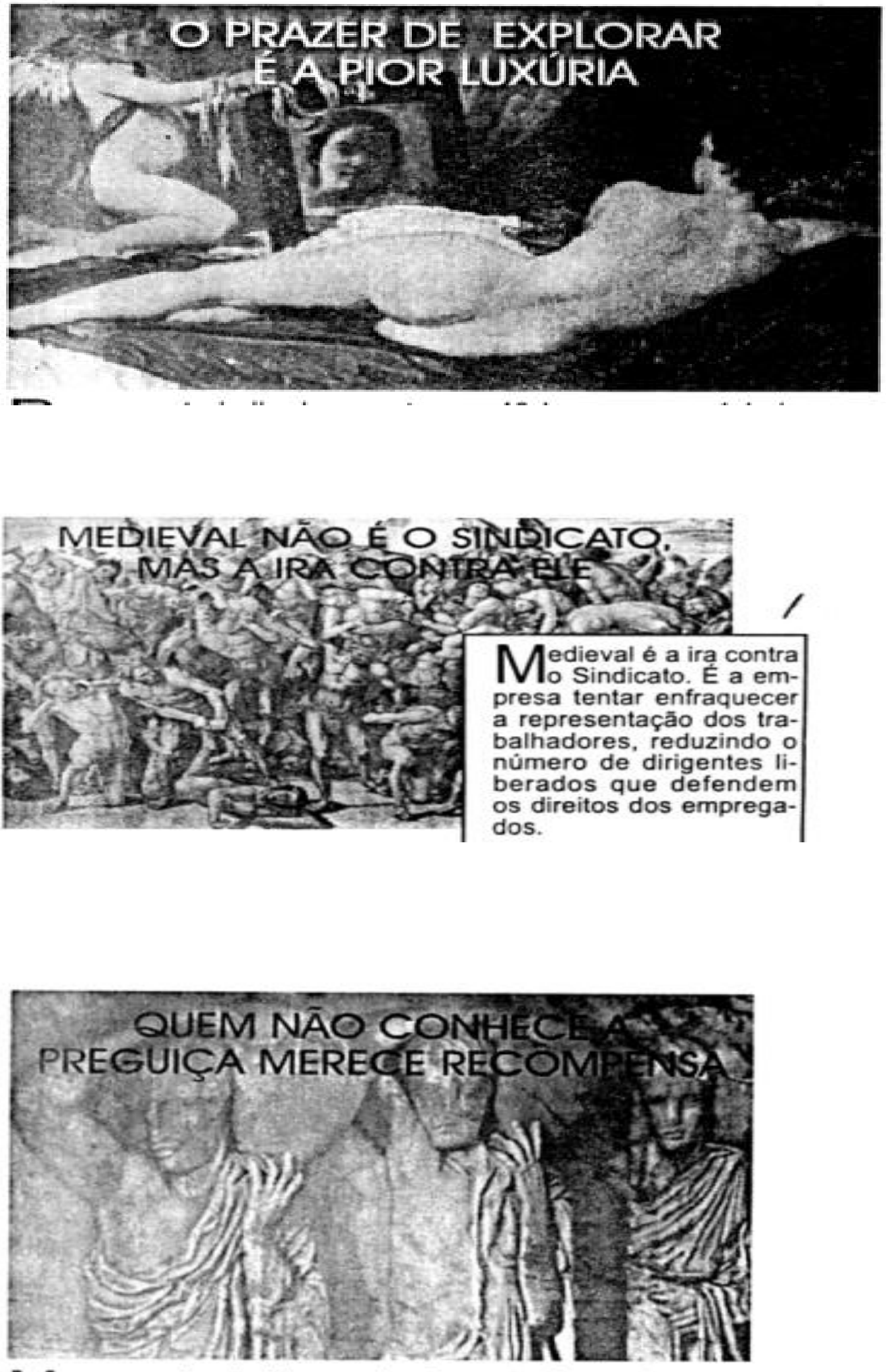

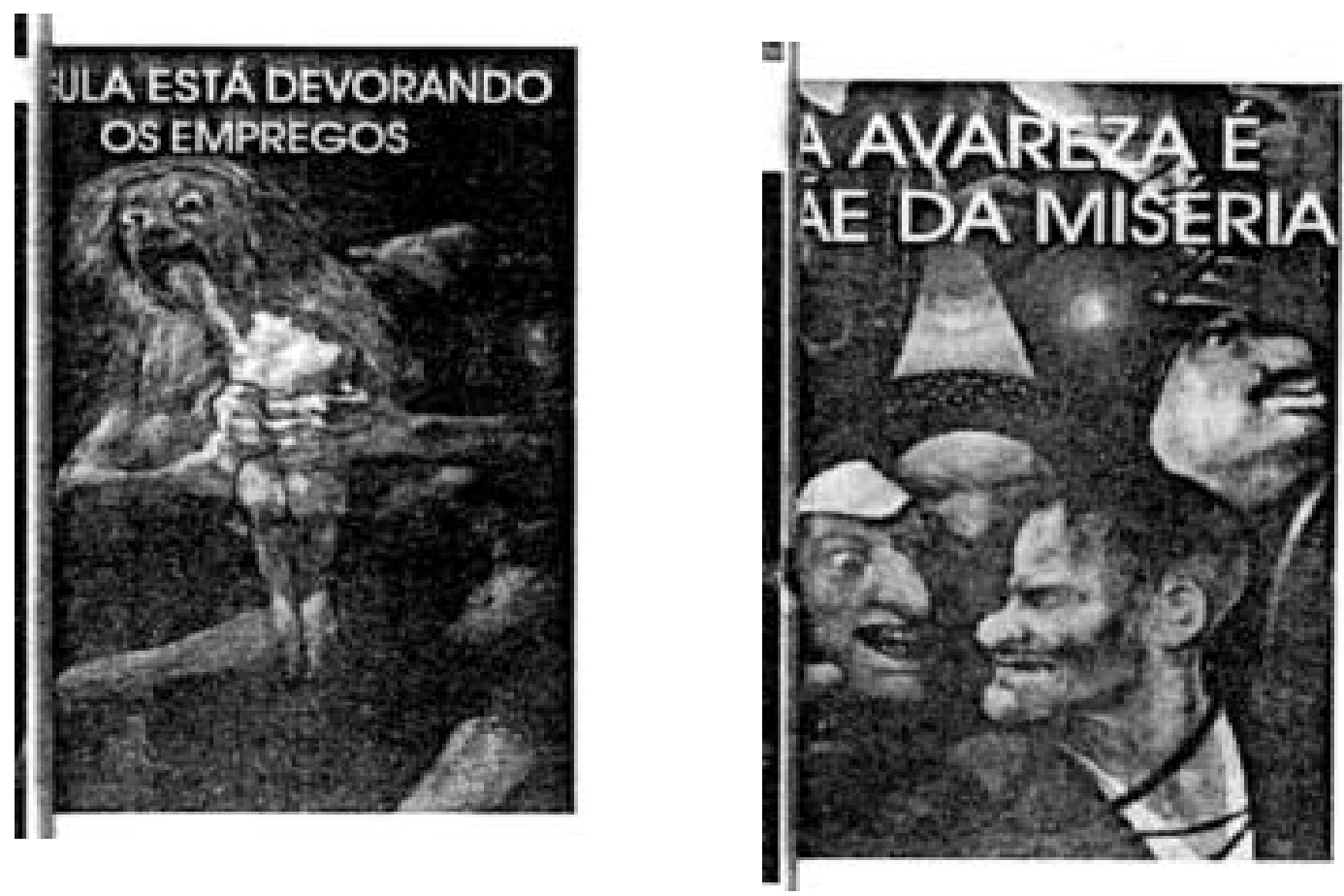

FIGURA 3: Os sete pecados capitais da TELEMAR FONTE: Bodim, dez. 1998

Os discursos elaborados pelo sindicato foram muito bem articulados, colocando efetivamente a empresa sob a identificação de 'grande pecadora', grande exploradora do trabalho dos empregados, gananciosa por lucros, arcaica nas relações de trabalho, descomprometida com a sociedade brasileira e seu enorme desemprego etc., buscando mostrar que quem verdadeiramente age contra os empregados é a diretoria da empresa, ao reduzir o número de empregos, acabar com os benefícios conquistados, reduzir o diálogo e aumentar a exploração das pessoas, demitindo-as e controlando-as.

$\mathrm{Na}$ visão do sindicato, ele próprio e os trabalhadores eram os que conheciam melhor a empresa:

"Nós conhecemos, sim, a Telemar, a "nossa empresa", que não nasceu em julho, quando da privatização, mas foi erguida com muito trabalho e esforço, ao longo de anos. Por isso, não podemos permitir que nos tirem o nosso passado e passem o rolo compressor em cima dos nossos direitos."(Bodim Especial, 30/04/1999).

Esse fragmento discursivo traduz com exatidão o modo como o grupo sindical realmente vê os novos proprietários e a nova direção. Na sua visão, a alta administração é 
composta de pessoas que não têm identificação com a ex-Telemig, com a história da empresa. Além do mais, só lhes interessa obter grandes lucros; desrespeitam os empregados, fazendo inúmeras retaliações, etc. Para o sindicato, tanto a ex-Telemig como os empregados e o próprio sindicato têm uma história (juntos) de construção da empresa: a "nossa empresa", que se refere agora também à Telemar e não somente à Telemar-Minas. Há um sentido maior nesse fragmento: o sindicato e os empregados conhecem suas respectivas ex-empresas regionais e, como ambos são intrinsecamente ligados, a soma dos dois os faz conhecer a Telemar como um todo.

\section{Considerações Finais}

Ao se analisar o conjunto de metáforas e narrativas, que estariam sustentando uma transformação das identidades da Telemig em Telemar-Minas, pode-se observar várias facetas dos discursos organizacionais.

Mesmo sendo uma das principais mudanças que a alta administração buscava implementar, a identidade aparece nos momentos - antes e depois da privatização - com semelhantes metáforas sendo utilizadas para definir a empresa. Ao fundo das narrativas o que aparece é a intenção da diretoria em promover uma nova identidade, não mais calcada na tecnologia, mas que se sustentaria na prestação de serviços, no aprimoramento dos processos de atendimento aos clientes, objetivando um novo olhar sobre as demandas do mercado. Há um sentido maior de, afinal era preciso entregar a empresa. Vale registar que as diretorias de antes da privatização estão imbuídas de entregar a empresa transformada para os novos proprietários, estratégia que parece ter sido alcançada pela semelhança das duas metáforas usadas: a número 1 e a referência.

A transformação de Telemig em Telemar-Minas, a perda da autonomia e do aparecimento de subserviência às estratégias e decisões de uma matriz, em um primeiro momento, serviu para fazer aparecer tanto nos gerentes como nos técnicos uma identificação contrária a da grande família ou mãe que era a Telemig - mesmo que em algumas narrativas percebeu-se o desenvolvimento de temas que mostram uma tentativa de adaptação à nova identidade de filial privada, sustentando um certo orgulho pela perda de pessoas para a holding, pois estaria resultando uma mineirização da Telemar. $\mathrm{Na}$ maioria das falas dos gerentes, a metáfora predominante é a da vaca leiteira da Telemar-Minas, no sentido desta

estar fornecendo pessoas para as outras filiais e matriz, ocasionando uma perda para a empresa. Todavia, a vaca leiteira também se aproxima do sentido da empresa ser uma 
referência para as outras empresas, apontando que, aos poucos, os gerentes estão introjetando os discursos e a identidade elaborada pela alta administração.

As narrativas e, principalmente, as metáforas usadas pelos técnicos revelam a perda de identificação para com a empresa Para esses técnicos, a identidade construída com base na metáfora da mãe estaria seriamente comprometida e seria diretamente substituída pela da madrasta que aparece, proporcionalmente, ao corte dos benefícios conquistados quando empresa pública. A madrasta, a "Telemá", retiraria a seguridade do emprego e ganhos duramente conquistados, além de estar exigindo cada vez mais horas de trabalho e sem recompensas para essas horas extras. Para esse grupo de pessoas, a transformação na identidade da empresa realmente produziu uma mudança profunda em suas histórias enquanto técnicos e na da organização enquanto Telemig, enquanto empresa pública e não de negócios privados.

Por parte do grupo do sindicato, pode-se evidenciar que há a tentativa de mostrar que a empresa não era uma caverna segura como consideravam muitos empregados, e que uma possível privatização já se anunciava mesmo no começo da década. Quanto à metáfora "grande pecadora" observa-se, em seu uso nos discursos desse grupo, que ela aparece vinculada à visão de que a empresa estava realmente rompendo uma profunda identificação com os trabalhadores, identificação que possibilitou a construção de fortes vínculos entre estes e a empresa, identificação que o próprio grupo do sindicato também ajudou a construir.

Por fim, o que se pode falar ainda sobre a transformação das identidades por qual passaria a empresa é que esta é vista de forma muito diversa para os grupos que compõem a ex-Telemig. Para alguns ainda essa transformação foi uma verdadeira quebra de paradigmas. Paradigmas culturais que estariam se rompendo desde o começo da década de noventa, e que continuam sendo rompidos até o momento, até pelas atuais diretorias da holding e TelemarMinas. Já para um grupo pequeno desses atores, as mudanças de identidades não ocorreram totalmente por causa somente da privatização, não são de total responsabilidade das atuais diretorias, mas na verdade são consequiências de um processo histórico por qual também passa o país que busca se adequar aos discursos dos países centrais e nesse processo perde também sua identidade.

A transformação organizacional por qual passou a Telemig/Telemar pode ser considerada um processo interativo, de muitos níveis, com os resultados emergindo não apenas como um produto de debates racionais ou limitadamente racionais, mas também moldados pelos interesses e comprometimentos de indivíduos e grupos, pelas forças burocráticas, pelo intercâmbio no ambiente e pela manipulação do contexto estrutural em 
torno de decisões. Assim, o foco de atenção também foi ver a mudança como um processo contínuo, de muitos níveis, principalmente simbólico, onde a "liderança" estaria expressa no entendimento e habilidades táticas, tanto como uma força com o propósito de mobilizar visões muitas vezes imprecisas e não articuladas, usadas para desafiar as crenças dominantes e os arranjos institucionais.

\section{Bibliografia:}

ALBERT, S. The definition and metadefinition of identity. In: WHETTEN, D. A.; GODFREY, P. C (Eds.). Identity in Organizations: building theory through conversations. London: Sage, 1998. p. 1-16.

ALBERT, S.; WHETTEN, D. A. Organizational identity. Research in Organizational Behavior, London, v. 7, p. 263-295, 1985.

ALVESSON, M. The business concept as a symbol. International Studies of Management \& Organization, Armonk, v.28, n. 3, p. 86-108, 1998.

Talking in organizations: managing identity and impressions about an advertising agency. Organization Studies, Berlin, v. 15, n. 4, p. 535-563, 1994.

ASHFORTH, B. E. What have we learned, and where do we go from here? In: WHETTEN, D. A.; GODFREY, P. C (Eds.). Identity in Organizations: building theory through conversations. London: Sage, 1998. p.268-272.

BALMER, J. M. T. e WILSON, A. 1998. 'Corporate identity'. International Studies of Management \& Organization, 3: 12-31.

BODIM ESPECIAL, Belo Horizonte: Sinttel, 30/04/1999.

BODIM SEMANAL, Belo Horizonte: Sinttel, março,1994.

BODIM SEMANAL, Belo Horizonte: Sinttel, junho,1994.

BODIM SEMANAL, Belo Horizonte: Sinttel, julho,1994.

BODIM SEMANAL, Belo Horizonte: Sinttel, dezembro,1998.

BORZEIX, A.; LINHART, D. 1996. Identidades e práticas lingüísticas na empresa. In CHANLAT, J. F. (Org.). O indivíduo na organização: dimensões esquecidas. São Paulo: Atlas. 1996. volume 3, p.82-106.

CALDAS, M P.; WOOD JÚNIOR., T. Identidade organizacional. Revista de Administração de Empresas, São Paulo, v. 37, n. 1, p. 6-17, 1997. 
CHANLAT, J. F. Por uma antropologia da condição humana nas organizações. In CHANLAT, J. F. (Org.).O Indivíduo na Organização: dimensões esquecidas. São Paulo: Atlas, 1992. volume 1, p.21-45.

CONSTRUINDO A TRANSFORMAÇÃO. Belo Horizonte: TELEMIG, 1995.

DAVEL, E. e MACHADO, H. V.. O Processo de Identificação nas Organizações. Revista Administração Contemporânea, Curitiba, v.5, n.3, p. 15 - 30, 2001.

DDdicas. Belo Horizonte: Telemig, janeiro-dezembro, 1998.

DDdicas. Belo Horizonte: Telemig, janeiro-abril, 1999.

DU GAY, P.; SALAMAN, G.; REES, B. The conduct of management and the management of conduct: contemporary managerial discourse and the constitution of the 'competent' manager. Journal of Management Studies, Oxford, v. 33, n. 3, p. 263-282, 1996.

DUTTON, J. E.; DUKERICH, J. M. Keeping an eye on the mirror: image and identity in organizational adptation. The Academy of Management Journal, Madison, v. 34, n. 3, p. 517-554, 1991.

FEATHERSTONE, M. Undoing Culture: Globalization, Postmodernism and Identity. London: Sage, 1995.

FIOL, M.; HATCH, M. J.; GOLDEN-BIDDLE, K. Organizational culture and identity: what's the difference anyway? In: WHETTEN, D. A.; GODFREY, P. C (Eds.). Identity in Organizations: building theory through conversations. London: Sage, 1998. p.56-62

FREITAS, M. E. Contexto social e imaginário organizacional moderno. Revista de Administração de Empresas, 2: 6-15, 2000.

FREITAS, M. E. Cultura Organizacional, Identidade, Sedução e Carisma? $2^{\mathrm{a}}$ edição. Rio de Janeiro: Editora FGV, 2000 .

FRIEDMAN, J. Cultural Identity and Global Process. London: Sage, 1994.

GLYNN, M. A.; ABZUG, R. Institutionalizing identity: determinants and effects of symbolic isomorphism on organizational names. Academy of Management Journal (Special Research Forum on Institutional Theory and Institutional Change), 2001. Forthing coming.

GRANT, D; OSWICK, C. Introduction: getting the measure of metaphors. In: GRANT, D.; OSWICK, C. (Eds.). Metaphor and Organizations. London: Sage, 1996, p. 1-20.

INNS D.; JONES, P. Metaphor in organization theory: following in the footsteps of the poet?. In: GRANT, D.; OSWICK, C. (Eds.). Metaphor and Organizations. London: Sage, 1996. p.110-126

LINHA DIRETA. Belo Horizonte: Telemig, dezembro, 1994. 
MACHADO-da-SILVA, C L; NOGUEIRA, E. P S. Instituições, cultura e identidade organizacional. Anais do ENEO 2000. Curitiba: Cromos Editora, 2000.

MANGHAM, I. L. Some consequences of taking Gareth Morgan seriously. In: GRANT, D.; OSWICK, C. (Eds.). Metaphor and Organizations. London: Sage, 1996, p.21-36.

MARTIN, J. Cultures in Organizations - Three Perspectives. Oxford: Oxford University Press, 1992.

MORGAN, G. Imagens da Organização. São Paulo: Atlas, 1996.

MUMBY, D. K; CLAIR R. P. Organizational discourse. In VAN DIJK (Org.). Discourse as Social Interaction. London: Sage. 1997. p. 181-205.

NKOMO, S. M.; COX JUNIOR., T. Diverse identities in organizational. In: CLEGG, S. R.; HARDY, C.; NORD, W. (Eds) Handbook of Organization Studies.. London: Sage, 1996. p.338-356.

O'CONNOR, E. S. Paradoxes of participation: textual analysis and organizational change. Organization Studies, Berlin, v. 16, n. 5, p. 769-803, 1995.

PUTNAM, L. L.; FAIRHURST, G. T. Discourse analysis in organizations. In: JABLIN, F. M.; PUTNAM, L. L. (Eds.) The New Handbook of Organizational Communication. Thousand Oaks, CA: Sage. 2001. 78-136.

RELATÓRIO ANUAL. Rio de Janeiro: Telemar, 1998

RODRIGUES, S. B Cultura Corporativa e Identidade: Desinstitucionalização em uma Companhia de Telecomunicação Brasileira. Belo Horizonte: UFMG, 1995. (mimeo)

O Chefinho, o Telefone e o Bode: autoritarismo e mudança cultural no setor de telecomunicações. Belo Horizonte: Cepead/UFMG, 1991. (Tese para concurso de Prof. Titular)

THIOLLENT, M. J. M. Crítica metodológica, investigação social e enquete operária. São Paulo: Polis, 1987.

VERSIANI, A. F. A identidade gerencial no contexto da globalização econômica: perspectivas e dilemas. In: ENCONTRO NACIONAL DE PROGRAMAS DE PÓS-GRADUAÇÃO EM ADMINISTRAÇÃO, 19, 1995, João Pessoa. Anais... Rio de Janeiro: Anpad, 1995.

\footnotetext{
${ }^{\mathrm{i}}$ Uma primeira versão resumida deste trabalho foi apresentada na Anpad 2001.

${ }^{i i}$ Professor da PUCMinas, Membro do GGI/UFMG, Doutor pelo Cepead/UF|MG, mestre pela UFLA. Rua Dom José Gaspar, 500, Prédio 14, Belo Horizonte, MG. 30535-610. carrieri@ pucminas.br

iii Durante o período estudado passaram pela empresa três diretorias: uma de 1990 até 1995, outra de 1995 até 1998 e a de 1998 até 2000.

${ }^{\text {iv }}$ Ressalta-se que a empresa ainda é tratada como Telemig, sua mudança de nome - para Telemar - somente ocorreu em março/abril de 1999.
} 